\title{
Comparison of the Quality Adjusting of Nonlinear Models for Organs, Carcass and Body Components in Meat-Type (Coturnix Coturnix Coturnix) and Laying- Type (Coturnix Coturnix Japonica) Quail
}

"Author(s)
Grieser DO'
Furlan AC'
Ribeiro PM'
Zancanela V"
Del Vesco AP"
Gasparino E'
Zardin AMSO'
Marcato SM'
' Department of Animal Science, State
University of Maringá. Maringá, Brazil.
" Department of Animal Science, Federal
University Sergipe. Sergipe, Brazil.

\section{Mail Address}

Corresponding author e-mail address Daiane de Oliveira Grieser

Universidade Estadual de Maringa Ringgold standard institution - Departamento de Zootecnia - Rua Doutor Mário Clapplier Urbinatti, 724 E, Maringá, PR, Brazil 87020-900

Tel: $\quad 5544$ 9720-4269

Email: daianegrieser@gmail.com

\section{EKeywords}

Gompertz equation, growth parameters, breast, number of interaction, strains.

\section{ABSTRACT}

The objective of this study was to evaluate the adjustment quality of nonlinear models to data organs growth, carcass and body components of meat-type (Coturnix coturnix coturnix) and japanese laying-type (Coturnix coturnix japonica) quail. A total of 1350 quails from one to $42 \mathrm{~d}$ old were distributed in a completely randomized design, with five replicates each. To determine the organs growth (gut, heart, liver and gizzard), carcass and body components (wing, thigh and drumstick, back and breast), two quails per repetition were slaughtered weekly. The data were evaluated in function of different nonlinear models (Logistical, Brody, Richards, Von Bertalanffy and Gompertz). All models studied adjusted the data, differing in adjustment quality. Brody model showed the best description of gut length to all treatments. For the data gizzard weight, heart, liver and gut, the models that best adjusted, presenting smaller residual mean square and numbers iterations were Gompertz and Logistical. The Gompertz, Logistic and Von Bertalanffy models were the most adequate to describe the thigh and drumstick growth, back and breast, and Gompertz models and Logistic to describe the wing growth and carcass, showing lesser number of iterations to achieve the convergence of date, as well as low residual mean square and squares sums of the regression residuals. The Gompertz model was the most appropriate to describe the organs growth and body components in meat- and laying-type quail when evaluated in growth phase.

\section{INTRODUCTION}

The development of the bird as a whole can be interpreted as the sum of the organs weights and parts, where each part has its own characteristics of growth, which should be evaluated in ideal conditions or not limiting, for the occurrence the of expression of their maximum genetic potential.

There are several factors that interfere in the growth curves, as well as: genetics, gender, nutrition, management and ambience. The bird's growth study is very important in animal production, for providing data which can be used to optimize the quail's growth, in order to increase the size of the prime cuts, keeping the proper size of the organs, thereby avoiding future metabolic disorders (Marcato, 2010).

There are many nonlinear models that may be used to describe the growth, but Gompertz has been more recommended by many authors, and showed better adjustment (Pasternak \& Shalev, 1994; Hancock et al., 1995; Gous et al., 1999; Sakomura et al., 2005; Neme et al., 2006; Marcato, 2010; Narinc et al., 2010; Finco et al., 2016).

One of the main advantages that the simulation of growth through mathematical models provides is an estimate of the parts; weight and 
organs at a specific age and concentrate information (daily gain rate, size at maturity, age of maximum growth, among others) of a population in a few easily interpretable parameters (Freitas et al., 1983). All this information helps the producer and the industry in making decisions in relation to the best age for slaughter, the quail's feed, in addition of genetic improvement, increasing carcass weight and specific prime cuts to meet the internal markets and of export.

Considering these aspects, this study aimed to evaluate the adjustment quality of nonlinear models to date organ growth (gut, heart, liver and gizzard), carcass and body components (wing, thigh and drumstick, back and breast) of meat-type (Coturnix coturnix coturnix) and japanese laying-type (Coturnix coturnix japonica) quail.

\section{MATERIALS AND METHODS}

\section{Animals and diets}

The following experimental procedure was approved by the ethics committee on the use of animals (CEUA) of the State University of Maringá (UEM) (Protocol No. 061/2012).

A total of 1350 non-sexed quails of one day of age were used, consisting of 400 of the meat-type quail strain (Coturnix coturnix coturnix), 450 of the yellow laying strain (Coturnix coturnix japonica) and 500 of the red laying strain (Coturnix coturnix japonica). The meat-type strain is used commercially and the yellow and red are laying strains that were genetically improved in the genetic improvement program of the UEM.

The quails were housed in a conventional shed, divided into 15 cages of $5.0 \mathrm{~m}^{2}$, where each cage was considered an experimental unit. It They were distributed in a completely randomized design with three treatments (each treatment corresponded to one quail strain) and five replicates with 80 birds per experimental unit of the meat-type quail strain, 90 birds of the yellow strain and 100 birds of the red strain. The experimental period was from 1 to 42 days of age.

Throughout the experimental period, the quail were raised in a conventional system, receiving feed and water ad libitum. The formulated diets were based on maize and soya bean meal and the values for feed chemical composition were determined according to Rostagno et al. (2011) depending on the nutritional requirements of quails at different stages of growth (Table 1).
Table 1 - Proximate, chemical and energy composition of feeds for meat-type and layer quail of 1-14 and 15-42 d of age and laying quail (yellow and red)

\begin{tabular}{|c|c|c|c|}
\hline & \multicolumn{2}{|c|}{ Meat-type quail } & \multirow{2}{*}{$\begin{array}{l}\text { Laying quail } \\
1-42 \mathrm{~d} \text { of age }\end{array}$} \\
\hline & $1-14 d$ & $15-42 d$ & \\
\hline Ingredients & \multicolumn{3}{|c|}{ Quantity (g/kg) } \\
\hline Corn & 409.5 & 527.9 & 571.6 \\
\hline Soybean meal (45\%) & 497.4 & 393.1 & 380.5 \\
\hline Soybean oil & 47.5 & 32.5 & 11.0 \\
\hline Dicalcium phosphate & 15.6 & 16.0 & 14.1 \\
\hline Salt & 4.6 & 4.6 & 3.9 \\
\hline Limestone & 3.6 & 2.8 & 11.6 \\
\hline DL-Methionine & 6.7 & 6.6 & 1.9 \\
\hline L- Lysine HCL & 6.8 & 8.0 & 0.5 \\
\hline L-Threonine & 4.2 & 4.1 & 0.9 \\
\hline L-Tryptophan & 0.1 & 0.4 & - \\
\hline Vitamin and mineral mixture ${ }^{1}$ & 4.0 & 4.0 & 4.0 \\
\hline \multicolumn{4}{|l|}{ Calculated Values } \\
\hline Metabolizable Energy (MJ/kg) & 12.5 & 12.7 & 12.2 \\
\hline Crude Protein (g/kg) & 275.0 & 235.0 & 220.0 \\
\hline Calcium (g/kg) & 6.4 & 6.1 & 9.0 \\
\hline Available phosphorus (g/kg) & 4.1 & 4.1 & 3.7 \\
\hline Sodium (g/kg) & 2.0 & 2.0 & 1.8 \\
\hline Potassium (g/kg) & 10.2 & 8.6 & - \\
\hline Chlorine (g/kg) & 3.1 & 3.1 & - \\
\hline Methionine + digestible cystine ( $/ \mathrm{kg})$ & 13.2 & 12.3 & 7.6 \\
\hline Digestible lysine (g/kg) & 18.7 & 17.3 & 11.2 \\
\hline Digestible threonine $(\mathrm{g} / \mathrm{kg})$ & 12.5 & 11.1 & 7.9 \\
\hline Digestible tryptophan $(\mathrm{g} / \mathrm{kg})$ & 3.0 & 2.8 & - \\
\hline
\end{tabular}

'Vitamin/mineral supplementation (guaranteed levels per kilogram of diet): retinol acetate - 18,000 IU; cholecalciferol - $5000 \mathrm{IU}$; dl- $\alpha$-tocopheryl acetate - $16 \mathrm{mg}$; thiamine hydrochloride $-1.12 \mathrm{mg}$; riboflavina $-8 \mathrm{mg}$; pyridoxine hydrochloride $-2.1 \mathrm{mg}$; cyanocobalamin - $20 \mathrm{mcg}$; menadione nicotinamide bisulphite $-4.028 \mathrm{mg}$; D-calcium pantothenate - $16 \mathrm{mg}$; niacin acid - $40 \mathrm{mg}$; choline chloride - $560 \mathrm{mg}$; zinc oxide $126 \mathrm{mg}$; ferrous sulphate - $98 \mathrm{mg}$; manganese sulphate - $155 \mathrm{mg}$; copper sulphate $-30.624 \mathrm{mg}$; cobaltous sulfate heptahydrate $-0.4 \mathrm{mg}$; potassium iodate $-1.936 \mathrm{mg}$; sodium selenite $-0.508 \mathrm{mg}$; butylated hydroxytoluene $-0.02 \mathrm{mg}$.

\section{Organs weight and carcass components}

To determine the growth of organs and carcass components of the quails, the methodology described by Sakomura \& Rostagno (2016) was used. The slaughters were performed weekly for a total of five quails per treatment at one day of age and two quails per replicate (one male and one female) at 7, 14, 21, 28,35 and 42 days of age. The birds were selected based on the average body weight $( \pm 5 \%)$ in each experimental unit. Subsequently, the birds were fasted for six hours, weighed again and then slaughtered via electronarcosis and posterior displacement of the occipital bone and atlas. The gut length and the weight of the following carcass components and organs were measured post mortem: wings (weight of two wings together), thighs and drumsticks (weight of two thighs and drumsticks together), back, breast, heart, liver, gizzard and gut. 


\section{Statistical analysis}

Using values for carcass components and organs weights, growth curves were prepared (SAS Inst. Inc., Cary, NC) using the following non-linear models: Gompertz (Fialho, 1999), A.e $\mathrm{e}^{-\mathrm{e}-\mathrm{B}(\mathrm{t}-\mathrm{C})}$; Brody (1945), A (1 - Be-kt); Von Bertalanffy (1957), A (1 - Be-kt)3; Logistics (Nelder, 1961), A (1+Be-kt)-1 and Richards (1959), A $\left(1-\mathrm{Be}^{-\mathrm{kt}}\right)^{\mathrm{M}}$, where for all the models the parameter $A$ is the weight at maturity $(\mathrm{g}), \mathrm{K}$ is the maturity rate $\left(d^{-1}\right), B$ is a constant of integration without biological interpretation, except in Gompertz that has biological interpretation, representing the relative growth at the inflection point ( $\mathrm{g} / \mathrm{d}$ per $\mathrm{g}$ ); $\mathrm{M}$ e $\mathrm{C}$ represent the age (d) of the inflection point of the growth curve; $e$ is the neperian logarithm. For Brody model $m=1(\mathrm{~g} / \mathrm{d})$, Von Bertalanffy $m=3(\mathrm{~g} / \mathrm{d})$, Logistics $m=-1(\mathrm{~g} / \mathrm{d})$ and to Richards $m$ is the variable.

Parameter K (for Brody, Von Bertalanffy, Logistic and Richards) and $\mathrm{B}$ (for Gompertz), is the growth rate of the animal, in which the higher rate indicates that the animal growth is faster, requiring less time to reach the adult weight (Carneiro et al., 2014). Already, the

Table 2 - Estimated values of the nonlinear models parameters for weight of organs (gut, liver, gizzard and heart) in meattype quail

\begin{tabular}{|c|c|c|c|c|c|c|}
\hline & \multirow{2}{*}{ Parameters } & \multicolumn{5}{|c|}{ Estimated of the parameters of the models } \\
\hline & & Gompertz & Brody & Von Bertalanffy & Logistic & Richards \\
\hline \multirow{7}{*}{ 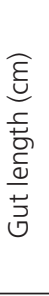 } & $A$ & 68.73 & 70.87 & 69.29 & 67.57 & 59.30 \\
\hline & $B$ & 0.12 & 0.78 & 0.37 & 2.33 & 80.13 \\
\hline & K & - & 0.08 & 0.11 & 0.16 & 7.00 \\
\hline & C & 2.32 & - & - & - & 15.00 \\
\hline & RMS & 46.24 & 44.10 & 45.47 & 48.63 & 137.00 \\
\hline & SSRR & 2867.0 & 2734.3 & 2819.0 & 3015.2 & 8631.1 \\
\hline & N iterations & 13 & 8 & 12 & 12 & 5 \\
\hline \multirow{7}{*}{ 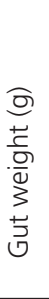 } & $A$ & 14.05 & 37.11 & 15.76 & 12.00 & 6.04 \\
\hline & B & 0.05 & 0.99 & 0.63 & 8.16 & -7834.20 \\
\hline & $K$ & - & 0.01 & 0.04 & 0.09 & 1295.70 \\
\hline & C & 18.92 & - & - & - & -489.40 \\
\hline & $R M S$ & 1.55 & 1.48 & 1.52 & 1.61 & 11.42 \\
\hline & SSRR & 96.0 & 91.9 & 94.5 & 99.7 & 730.6 \\
\hline & $N$ iterations & 8 & 12 & 23 & 7 & 17 \\
\hline \multirow{7}{*}{ 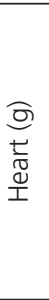 } & $A$ & 3.19 & 14.23 & 3.60 & 2.76 & 1.55 \\
\hline & B & 0.07 & 1.01 & 0.75 & 16.39 & -7.54 E14 \\
\hline & $K$ & - & 0.01 & 0.05 & 0.13 & 32.55 \\
\hline & C & 18.76 & - & - & - & -1.45 \\
\hline & $R M S$ & 0.10 & 0.11 & 0.10 & 0.09 & 0.68 \\
\hline & SSRR & 5.9 & 6.5 & 6.1 & 5.6 & 42.7 \\
\hline & $N$ iterations & 9 & 17 & 10 & 9 & 20 \\
\hline \multirow{7}{*}{$\begin{array}{l}\text { O्रे } \\
\text {.্े }\end{array}$} & $A$ & 7.18 & 4.08 & 7.66 & 6.55 & 4.08 \\
\hline & B & 0.07 & 373.60 & 0.62 & 7.64 & 174.70 \\
\hline & $K$ & - & 6.00 & 0.05 & 0.11 & 7.00 \\
\hline & C & 14.28 & - & - & - & 15.00 \\
\hline & $R M S$ & 0.87 & 3.40 & 0.86 & 0.90 & 3.40 \\
\hline & SSRR & 53.9 & 214.4 & 53.4 & 55.6 & 214.4 \\
\hline & $N$ iterations & 8 & 2 & 9 & 8 & 7 \\
\hline \multirow{7}{*}{ 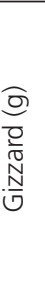 } & $A$ & 5.54 & 4.22 & 5.62 & 5.43 & 4.22 \\
\hline & $B$ & 0.13 & 363.10 & 0.70 & 8.87 & 156.10 \\
\hline & $K$ & - & 6.00 & 0.11 & 0.18 & 7.00 \\
\hline & $C$ & 8.61 & - & - & - & 15.00 \\
\hline & RMS & 0.76 & 2.47 & 0.77 & 0.74 & 2.47 \\
\hline & SSRR & 46.9 & 155.5 & 47.5 & 46.1 & 155.5 \\
\hline & $N$ iterations & 10 & 2 & 10 & 11 & 6 \\
\hline
\end{tabular}

Residual mean square (RMS); squares sum of the regression residuals (SSRR); number (N). For Brody, Von Bertalanffy, Logistic and Richards, the parameter A ( $g$ ) is the weight at maturity, $K\left(\mathrm{~d}^{-1}\right)$ is the maturity rate, B is a constant of integration without biological interpretation and C for Richards is also the integration constant. For Gompertz, A ( $\mathrm{g}$ ) is the maturity weight; $B\left(d^{-1}\right)$ is the maturity rate and $C(d)$ is the time to maximal growth. 
parameter $C$ for Gompertz means the age at which the animal's growth rate is maximal, that is, the inflection point of the curve goes from increasing to decreasing, where daily weight gains begin to decrease gradually (Freitas, 2005).

To choose the most appropriate model, the adjustment quality to the data was taken into consideration as well as the following criteria: convergence of the models, residual mean square (RMS) and square sum of the regression residuals (SSRR) beyond the factor of computational difficulty of the adjustment model, which relates to the number of iterations for convergence of functions. Therefore, the higher values of the RMS and SSRR and the higher numbers of iterations, the quality of adjustment of the non-linear models to the date is worse, and It is not indicated to describe the growth of the animals.

\section{RESULTS}

\section{Organs growth}

All analyzed models adjusted to the data, however they differ in the adjustment quality (Table 2, 3 and 4).

The Brody model was the best to describe gut growth (weight and length), in meat-type quail (Table 2), given its RMS (1.48 and 44.10) and greater

Table 3 - Estimated values of the nonlinear models parameters for weight of organs (gut, liver, gizzard and heart) in red laying quail

\begin{tabular}{|c|c|c|c|c|c|c|}
\hline & \multirow{2}{*}{ Parameters } & \multicolumn{5}{|c|}{ Estimated of the parameters of the models } \\
\hline & & Gompertz & Brody & Von Bertalanffy & Logistic & Richards \\
\hline \multirow{7}{*}{ 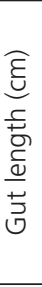 } & $A$ & 59.25 & 62.52 & 60.06 & 57.70 & 46.84 \\
\hline & $B$ & 0.08 & 0.75 & 0.35 & 2.12 & 68.89 \\
\hline & K & - & 0.05 & 0.07 & 0.11 & 7.00 \\
\hline & C & 2.61 & - & - & - & 15.00 \\
\hline & RMS & 15.73 & 15.37 & 15.57 & 16.32 & 98.11 \\
\hline & $S S R R$ & 975.1 & 952.6 & 965.3 & 1011.8 & 6181.0 \\
\hline & $N$ iterations & 7 & 5 & 9 & 7 & 5 \\
\hline \multirow{7}{*}{ 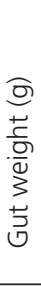 } & $A$ & 9.40 & 36.42 & 10.74 & 7.93 & 4.10 \\
\hline & $B$ & 0.06 & 1.00 & 0.65 & 9.75 & -792.60 \\
\hline & $K$ & - & 0.01 & 0.04 & 0.10 & 277.50 \\
\hline & $C$ & 18.85 & - & - & - & -8.40 \\
\hline & RMS & 0.70 & 0.71 & 0.70 & 0.70 & 5.54 \\
\hline & $S S R R$ & 43.6 & 44.3 & 43.7 & 43.6 & 354.6 \\
\hline & $N$ iterations & 7 & 13 & 8 & 7 & 18 \\
\hline \multirow{7}{*}{$\begin{array}{l}\text { क्रि } \\
\underset{\frac{\pi}{0}}{\mathbb{0}} \\
\frac{1}{1}\end{array}$} & $A$ & 2.29 & 0.92 & 2.86 & 1.78 & 0.92 \\
\hline & $B$ & 0.05 & 364.10 & 0.69 & 12.15 & -1563.60 \\
\hline & $K$ & - & 6.00 & 0.03 & 0.11 & 10.16 \\
\hline & C & 22.55 & - & - & - & -39.78 \\
\hline & $R M S$ & 0.02 & 0.22 & 0.03 & 0.02 & 0.22 \\
\hline & SSRR & 1.5 & 13.9 & 1.5 & 1.5 & 13.9 \\
\hline & $N$ iterations & 7 & 2 & 9 & 7 & 19 \\
\hline \multirow{7}{*}{ 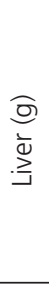 } & $A$ & 3.74 & 2.35 & 3.91 & 3.51 & 2.35 \\
\hline & $B$ & 0.08 & 366.60 & 0.67 & 9.63 & 161.80 \\
\hline & $K$ & - & 6.00 & 0.07 & 0.14 & 7.00 \\
\hline & $C$ & 12.67 & - & - & - & 15.00 \\
\hline & RMS & 0.22 & 1.05 & 0.22 & 0.21 & 1.05 \\
\hline & SSRR & 13.6 & 65.9 & 13.8 & 13.2 & 65.9 \\
\hline & $N$ iterations & 10 & 2 & 10 & 9 & 6 \\
\hline \multirow{7}{*}{ 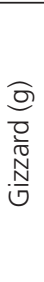 } & $A$ & 3.62 & 2.46 & 3.75 & 3.43 & 2.46 \\
\hline & $B$ & 0.08 & 343.70 & 0.56 & 6.14 & 131.10 \\
\hline & $K$ & - & 6.00 & 0.07 & 0.13 & 7.00 \\
\hline & $C$ & 9.93 & - & - & - & 15.00 \\
\hline & $R M S$ & 0.13 & 0.76 & 0.13 & 0.13 & 0.76 \\
\hline & SSRR & 8.2 & 48.1 & 8.3 & 8.1 & 48.1 \\
\hline & $N$ iterations & 6 & 2 & 8 & 8 & 6 \\
\hline
\end{tabular}

Residual mean square (RMS); squares sum of the regression residuals (SSRR); number (N). For Brody, Von Bertalanffy, Logistic and Richards, the parameter A ( $g$ ) is the weight at maturity, $K\left(d^{-1}\right)$ is the maturity rate, B is a constant of integration without biological interpretation and C for Richards is also the integration constant. For Gompertz, $A$ ( $g$ ) is the maturity weight; $B\left(d^{-1}\right)$ is the maturity rate and $C(d)$ is the time to maximal growth. 
computational speed, with iteration numbers of 12 and 8 . For the heart, these same models best adjusted, with RMS (0.10 and 0.09, respectively) and SSRR (5.9 and 5.6, respectively), beyond a smaller number of iterations for convergence of data ( 9 for both models, respectively). With relation to the liver weight, the Gompertz models and Von Bertalanffy, respectively, were considered the most appropriate, because it had lower SSRR (53.9 and 53.4). The gizzard showed better adjustment to the Gompertz models and Logistic, because they have shown smaller RMS (0.76 and 0.74 , respectively) and SSRR (46.9 and 46.1, respectively).
According to Table 3, the Gompertz models and Logistic best describe the gut (weight) growth, heart, liver and gizzard in red laying quail. For the gut (weight) growth, the Gompertz model and Logistic showed the same values of RMS (0.70) number of iterations (7) and SSRR (43.6). For heart variable, the same models were chosen because they have the same RMS (0.02) SSRR (1.5) and number of iterations (7). O Gompertz model to the liver present a low RMS (0.22), and to the gizzard has low RMS (0.13), SSRR (8.2) and number of iterations (6). The Logistical model and Von Bertalanffy also showed good adjustment, but with values very close to the Gompertz. The model that best adjust the

Table 4 - Estimated values of the nonlinear models parameters for weight of organs (gut, heart, liver and gizzard) in yellow laying quail

\begin{tabular}{|c|c|c|c|c|c|c|}
\hline \multirow{2}{*}{ 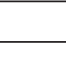 } & \multirow{2}{*}{ Parameters } & \multicolumn{5}{|c|}{ Estimated of the parameters of the models } \\
\hline & & Gompertz & Brody & Von Bertalanffy & Logistic & Richards \\
\hline \multirow{7}{*}{ 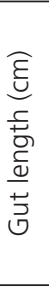 } & $A$ & 47.61 & 48.31 & 47.81 & 47.20 & 43.25 \\
\hline & $B$ & 0.16 & 0.79 & 0.37 & 2.44 & 78.48 \\
\hline & $K$ & - & 0.12 & 0.14 & 0.21 & 7.00 \\
\hline & C & 1.89 & - & - & - & 15.00 \\
\hline & RMS & 17.24 & 16.84 & 17.07 & 17.92 & 48.65 \\
\hline & SSRR & 1069.1 & 1044.4 & 1058.2 & 1110.9 & 3065.1 \\
\hline & $N$ iterations & 10 & 6 & 9 & 8 & 5 \\
\hline \multirow{7}{*}{ 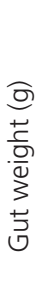 } & $A$ & 5.65 & 7.01 & 5.87 & 5.32 & 3.52 \\
\hline & $B$ & 0.07 & 0.98 & 0.57 & 5.65 & -6.191 E7 \\
\hline & $K$ & - & 0.03 & 0.06 & 0.11 & 21.03 \\
\hline & C & 11.63 & - & - & - & -58.44 \\
\hline & RMS & 0.45 & 0.43 & 0.45 & 0.48 & 1.83 \\
\hline & SSRR & 28.2 & 26.7 & 27.7 & 29.5 & 115.1 \\
\hline & $N$ iterations & 9 & 5 & 7 & 8 & 20 \\
\hline \multirow{7}{*}{ 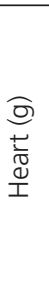 } & $A$ & 2.01 & 0.89 & 2.40 & 1.64 & 0.89 \\
\hline & $B$ & 0.05 & 348.30 & 0.67 & 11.36 & 136.30 \\
\hline & $K$ & - & 6.00 & 0.04 & 0.11 & 7.00 \\
\hline & C & 20.19 & - & - & - & 15.00 \\
\hline & RMS & 0.03 & 0.20 & 0.03 & 0.03 & 0.20 \\
\hline & SSRR & 2.0 & 12.8 & 2.0 & 1.9 & 12.8 \\
\hline & $N$ iterations & 9 & 2 & 10 & 8 & 6 \\
\hline \multirow{7}{*}{$\begin{array}{l}\text { O्रे } \\
\text { ¿্े }\end{array}$} & $A$ & 3.71 & 2.33 & 3.88 & 3.48 & 2.33 \\
\hline & $B$ & 0.08 & 375.30 & 0.68 & 9.43 & 178.50 \\
\hline & $K$ & - & 6.00 & 0.07 & 0.14 & 7.00 \\
\hline & $C$ & 12.71 & - & - & - & 15.00 \\
\hline & RMS & 0.30 & 1.12 & 0.30 & 0.30 & 1.12 \\
\hline & SSRR & 18.8 & 70.6 & 18.9 & 18.9 & 70.6 \\
\hline & $N$ iterations & 9 & 2 & 9 & 8 & 7 \\
\hline \multirow{7}{*}{ 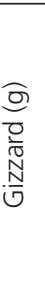 } & $A$ & 3.36 & 2.49 & 3.43 & 3.25 & 2.49 \\
\hline & $B$ & 0.11 & 349.70 & 0.60 & 6.70 & 138.00 \\
\hline & $K$ & - & 6.00 & 0.09 & 0.16 & 7.00 \\
\hline & C & 8.44 & - & - & - & 15.00 \\
\hline & $R M S$ & 0.21 & 0.77 & 0.21 & 0.21 & 0.77 \\
\hline & SSRR & 12.9 & 48.6 & 13.0 & 12.8 & 48.6 \\
\hline & $N$ iterations & 7 & 2 & 6 & 9 & 6 \\
\hline
\end{tabular}

Residual mean square (RMS); squares sum of the regression residuals (SSRR); number (N). For Brody, Von Bertalanffy, Logistic and Richards, the parameter A ( $\mathrm{g}$ ) is the weight at maturity, $K\left(\mathrm{~d}^{-1}\right)$ is the maturity rate, $B$ is a constant of integration without biological interpretation and C for Richards is also the integration constant. For Gompertz, $A$ ( $g$ ) is the maturity weight; $B\left(d^{-1}\right)$ is the maturity rate and $C(d)$ is the time to maximal growth. 
intestine length was Brody with RMS (15.37), SSRR (952.6) and low number of iterations (5).

For yellow laying quail, Gompertz was also featured in adjustment quality among the models analyzed (Table 4). However, Brody better adjusted to the data of gut length, presenting low number of iterations (6), RMS (16.84) and SSRR (1044.4), already to the weight of gut, Gompertz presented low RMS (0.45). For weight of heart, Gompertz and Logistic were the best adjustment, showing smaller RMS $(0.03$ for both, respectively). Gompertz was the most appropriate to describe the gizzard growth and liver according to their number of iterations (7 and 9, respectively) and their smallest SSRR (0.21 and 0.30 , respectively).

\section{Component carcass growth}

All analyzed models adjusted to the data, however they differ in the adjustment quality (Table 5, 6 and 7).

For body components of meat-type quail data, (Table 5) the Gompertz model was the best adjustment to date to describe the wing growth, it is due the fact of this have shown a lower RMS $(0.90), \operatorname{SSRR}(55,6)$

Table 5 - Estimated values of the nonlinear models parameters for weight of carcass components (wings, thighs and drumsticks, back and breast) and carcass in meat-type quail

\begin{tabular}{|c|c|c|c|c|c|c|}
\hline & \multirow{2}{*}{ Parameters } & \multicolumn{5}{|c|}{ Estimated of the parameters of the models } \\
\hline & & Gompertz & Brody & Von Bertalanffy & Logistic & Richards \\
\hline \multirow{7}{*}{ 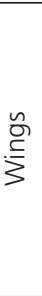 } & $A$ & 11.51 & 8.00 & 11.71 & 11.15 & 8.00 \\
\hline & $B$ & 0.13 & 391.60 & 1.07 & 22.22 & 230.00 \\
\hline & $K$ & - & 6.00 & 0.11 & 0.21 & 7.00 \\
\hline & C & 12.06 & - & - & - & 15.00 \\
\hline & RMS & 0.90 & 12.36 & 0.93 & 0.90 & 12.36 \\
\hline & $S S R R$ & 55.6 & 778.7 & 57.5 & 55.6 & 778.7 \\
\hline & $N$ iterations & 7 & 2 & 14 & 9 & 7 \\
\hline \multirow{7}{*}{ 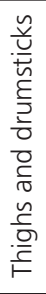 } & $A$ & 46.97 & 21.87 & 53.09 & 40.50 & 21.87 \\
\hline & $B$ & 0.07 & 384.70 & 0.80 & 17.25 & 202.90 \\
\hline & $K$ & - & 6.00 & 0.05 & 0.13 & 7.00 \\
\hline & $C$ & 19.72 & - & - & - & 15.00 \\
\hline & RMS & 2.58 & 135.30 & 2.58 & 3.05 & 135.30 \\
\hline & SSRR & 159.7 & 8523.5 & 160.2 & 189.0 & 8523.5 \\
\hline & $N$ iterations & 7 & 2 & 11 & 8 & 7 \\
\hline \multirow{7}{*}{ 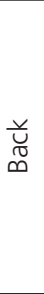 } & $A$ & 38.06 & 18.84 & 41.88 & 33.72 & 18.84 \\
\hline & $B$ & 0.07 & 376.70 & 0.76 & 13.88 & 181.50 \\
\hline & $K$ & - & 6.00 & 0.05 & 0.12 & 7.00 \\
\hline & $C$ & 18.20 & - & - & - & 15.00 \\
\hline & RMS & 8.67 & 96.20 & 8.59 & 9.18 & 96.20 \\
\hline & $S S R R$ & 537.6 & 6060.3 & 532.8 & 568.9 & 6060.3 \\
\hline & $N$ iterations & 7 & 2 & 12 & 8 & 6 \\
\hline \multirow{7}{*}{ 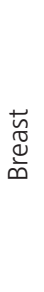 } & $A$ & 80.49 & 36.35 & 89.94 & 70.23 & 36.35 \\
\hline & $B$ & 0.08 & 400.10 & 0.97 & 29.14 & 300.90 \\
\hline & $K$ & - & 6.00 & 0.06 & 0.14 & 7.00 \\
\hline & $C$ & 20.84 & - & - & - & 15.00 \\
\hline & RMS & 7.61 & 478.70 & 7.67 & 9.20 & 478.70 \\
\hline & $S S R R$ & 472.0 & 30161.0 & 475.2 & 570.5 & 30161.0 \\
\hline & $N$ iterations & 7 & 2 & 11 & 8 & 8 \\
\hline \multirow{7}{*}{$\frac{\widetilde{U}}{\stackrel{\tilde{U}}{\tilde{U}}}$} & $A$ & 174.70 & 85.06 & 85.06 & 154.60 & 85.06 \\
\hline & $B$ & 0.08 & 390.20 & 274.20 & 19.77 & 223.30 \\
\hline & $K$ & - & 6.00 & 6.00 & 0.14 & 7.00 \\
\hline & $C$ & 18.99 & - & - & - & 15.00 \\
\hline & RMS & 28.24 & 2127.30 & 2127.30 & 37.02 & 2127.30 \\
\hline & $S S R R$ & 1750.9 & 134021.0 & 134021.0 & 2295.5 & 134021.0 \\
\hline & $N$ iterations & 6 & 2 & 6 & 8 & 6 \\
\hline
\end{tabular}

Residual mean square (RMS); squares sum of the regression residuals (SSRR); number (N). For Brody, Von Bertalanffy, Logistic and Richards, the parameter A ( $g$ ) is the weight at maturity, $\mathrm{K}\left(\mathrm{d}^{-1}\right)$ is the maturity rate, $\mathrm{B}$ is a constant of integration without biological interpretation and C for Richards is also the integration constant. For Gompertz, $\mathrm{A}(\mathrm{g})$ is the maturity weight; $B\left(d^{-1}\right)$ is the maturity rate and $C(d)$ is the time to maximal growth. 
and number of iterations (7). The Von Bertalanffy model obtained better quality adjustment to date of weight of thigh and drumstick, back and breast, because it showed low values of RMS $(2.58$; 8.59; 7.67, respectively), but the Gompertz model stands out quality adjustment and for these variables showed a low number of iterations for convergence of data ( 7 , respectively).

In red laying quail, it was observed that the Gompertz models and Logistic were the most adequate to describe the wing growth, thigh, drumstick and breast (Table 6). The adjustment quality of Gompertz was better, because in all variables it had low RMS $(0.31 ; 0.88 ; 4.19)$, low SSRR $(19.5 ; 55.6 ; 259.9)$ and a smaller number of iterations for convergence of data $(6 ; 7 ; 7)$, respectively. For back, Gompertz was also the best model, with low values of RMS (1.89), SSRR (117.1) and iteration numbers (6).

The Gompertz and Logistic models were the most adequate to describe the wing growth and thigh and drumstick, being the first slightly higher, showing less numbers of iterations to achieve the convergence of

Table 6 - Estimated values of the nonlinear models parameters for weight of carcass components (wings, thighs and drumsticks, back and breast) and carcass in red laying quail

\begin{tabular}{|c|c|c|c|c|c|c|}
\hline & \multirow{2}{*}{ - Parameters } & \multicolumn{5}{|c|}{ Estimated of the parameters of the models } \\
\hline & & Gompertz & Brody & Von Bertalanffy & Logistic & Richards \\
\hline \multirow{7}{*}{$\stackrel{n}{\stackrel{n}{\complement}}$} & $A$ & 7.25 & 4.50 & 7.54 & 6.84 & 4.50 \\
\hline & $B$ & 0.10 & 387.30 & 0.87 & 16.58 & 211.80 \\
\hline & $K$ & - & 6.00 & 0.08 & 0.16 & 7.00 \\
\hline & C & 13.96 & - & - & - & 15.00 \\
\hline & RMS & 0.31 & 4.46 & 0.32 & 0.33 & 4.46 \\
\hline & SSRR & 19.5 & 281.2 & 19.8 & 20.3 & 281.2 \\
\hline & $N$ iterations & 6 & 2 & 10 & 8 & 7 \\
\hline \multirow{7}{*}{ 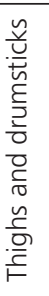 } & $A$ & 23.50 & 11.69 & 26.17 & 20.59 & 11.69 \\
\hline & $B$ & 0.07 & 375.90 & 0.82 & 19.17 & 179.70 \\
\hline & $K$ & - & 6.00 & 0.05 & 0.14 & 7.00 \\
\hline & C & 18.71 & - & - & - & 15.00 \\
\hline & RMS & 0.88 & 37.93 & 0.96 & 0.85 & 37.93 \\
\hline & SSRR & 55.6 & 2427.3 & 60.6 & 53.5 & 2427.3 \\
\hline & $N$ iterations & 7 & 2 & 9 & 8 & 6 \\
\hline \multirow{7}{*}{$\begin{array}{l}\stackrel{v}{\ddot{D}} \\
\text { D }\end{array}$} & $A$ & 21.51 & 10.66 & 23.94 & 18.89 & 10.66 \\
\hline & $B$ & 0.07 & 365.30 & 0.78 & 15.74 & 159.60 \\
\hline & $K$ & - & 6.00 & 0.05 & 0.13 & 7.00 \\
\hline & C & 18.31 & - & - & - & 15.00 \\
\hline & RMS & 1.89 & 31.23 & 1.92 & 8673.20 & 31.23 \\
\hline & SSRR & 117.1 & 1967.6 & 119.2 & 121.7 & 1967.6 \\
\hline & $N$ iterations & 6 & 2 & 13 & 9 & 6 \\
\hline \multirow{7}{*}{ 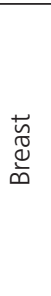 } & $A$ & 35.73 & 18.16 & 38.43 & 32.55 & 18.16 \\
\hline & $B$ & 0.09 & 398.30 & 1.11 & 37.34 & 277.10 \\
\hline & $K$ & - & 6.00 & 0.07 & 0.17 & 7.00 \\
\hline & C & 18.89 & - & - & - & 15.00 \\
\hline & $R M S$ & 4.19 & 117.10 & 4.47 & 4.04 & 117.10 \\
\hline & SSRR & 259.9 & 7377.8 & 277.0 & 250.4 & 7377.8 \\
\hline & $N$ iterations & 7 & 2 & 14 & 8 & 8 \\
\hline \multirow{7}{*}{ 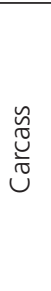 } & $A$ & 87.65 & 44.88 & 44.88 & 78.69 & 44.88 \\
\hline & $B$ & 0.08 & 383.50 & 255.40 & 22.86 & 199.30 \\
\hline & $K$ & - & 6.00 & 6.00 & 0.15 & 7.00 \\
\hline & $C$ & 18.17 & - & - & - & 15.00 \\
\hline & RMS & 10.34 & 591.80 & 591.80 & 10.33 & 591.80 \\
\hline & SSRR & 641.2 & 37281.2 & 37281.2 & 640.5 & 37281.2 \\
\hline & $N$ iterations & 6 & 2 & 6 & 8 & 6 \\
\hline
\end{tabular}

Residual mean square (RMS); squares sum of the regression residuals (SSRR); number (N). For Brody, Von Bertalanffy, Logistic and Richards, the parameter A ( $g$ ) is the weight at maturity, $\mathrm{K}\left(\mathrm{d}^{-1}\right)$ is the maturity rate, $\mathrm{B}$ is a constant of integration without biological interpretation and C for Richards is also the integration constant. For Gompertz, $\mathrm{A}(\mathrm{g})$ is the maturity weight; $B\left(d^{-1}\right)$ is the maturity rate and $C(d)$ is the time to maximal growth. 
data, as well as low SSRR and RMS (Table 7). For back and breast, Von Bertalanffy and Gompertz models showed better adjustment, being that Gompertz stood out presented lower values of RMS (1.66; 1.97, respectively) and number of iterations ( 7 for both, respectively).

Table 7 - Estimated values of the nonlinear models parameters for weight of carcass components (wings, thighs and drumsticks, back and breast) and carcass in yellow laying quail

\begin{tabular}{|c|c|c|c|c|c|c|}
\hline & \multirow{2}{*}{ Parameters } & \multicolumn{5}{|c|}{ Estimated of the parameters of the models } \\
\hline & & Gompertz & Brody & Von Bertalanffy & Logistic & Richards \\
\hline \multirow{7}{*}{ 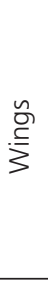 } & $A$ & 6.20 & 4.38 & 6.32 & 5.97 & 4.38 \\
\hline & $B$ & 0.14 & 384.30 & 1.14 & 33.42 & 201.60 \\
\hline & K & - & 6.00 & 0.12 & 0.24 & 7.00 \\
\hline & C & 11.92 & - & - & - & 15.00 \\
\hline & RMS & 1.58 & 4.96 & 1.60 & 1.56 & 4.96 \\
\hline & SSRR & 98.2 & 312.5 & 99.1 & 96.7 & 312.5 \\
\hline & $N$ iterations & 8 & 2 & 10 & 12 & 7 \\
\hline \multirow{7}{*}{ 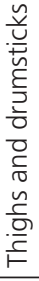 } & $A$ & 21.75 & 11.06 & 23.92 & 19.27 & 11.06 \\
\hline & $B$ & 0.08 & 373.10 & 0.81 & 17.52 & 173.70 \\
\hline & K & - & 6.00 & 0.06 & 0.14 & 7.00 \\
\hline & C & 17.71 & - & - & - & 15.00 \\
\hline & RMS & 0.91 & 32.75 & 0.96 & 0.94 & 32.75 \\
\hline & SSRR & 55.3 & 2030.2 & 58.5 & 57.4 & 2030.2 \\
\hline & $N$ iterations & 6 & 2 & 25 & 8 & 6 \\
\hline \multirow{7}{*}{$\begin{array}{l}\stackrel{\ddot{D}}{D} \\
\text {. }\end{array}$} & $A$ & 20.42 & 10.02 & 22.77 & 17.86 & 10.02 \\
\hline & $B$ & 0.07 & 365.00 & 0.74 & 13.07 & 159.10 \\
\hline & K & - & 6.00 & 0.05 & 0.12 & 7.00 \\
\hline & C & 18.28 & - & - & - & 15.00 \\
\hline & RMS & 1.66 & 25.65 & 1.66 & 1.77 & 25.65 \\
\hline & SSRR & 102.8 & 1615.8 & 102.8 & 109.5 & 1615.8 \\
\hline & $N$ iterations & 7 & 2 & 21 & 8 & 6 \\
\hline \multirow{7}{*}{ 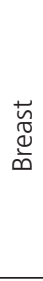 } & $A$ & 35.36 & 16.27 & 39.29 & 30.97 & 16.27 \\
\hline & $B$ & 0.08 & 396.80 & 0.93 & 25.82 & 262.60 \\
\hline & K & - & 6.00 & 0.06 & 0.14 & 7.00 \\
\hline & C & 20.10 & - & - & - & 15.00 \\
\hline & RMS & 1.97 & 90.99 & 1.98 & 2.29 & 90.99 \\
\hline & SSRR & 120.3 & 5641.5 & 120.8 & 139.8 & 5641.5 \\
\hline & $N$ iterations & 7 & 2 & 8 & 9 & 8 \\
\hline \multirow{7}{*}{ 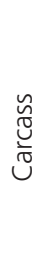 } & $A$ & 83.01 & 42.11 & 42.11 & 74.13 & 42.11 \\
\hline & $B$ & 0.08 & 381.30 & 250.20 & 17.85 & 193.00 \\
\hline & K & - & 6.00 & 6.00 & 0.14 & 7.00 \\
\hline & C & 18.06 & - & - & - & 15.00 \\
\hline & RMS & 7.35 & 494.60 & 494.60 & 9.34 & 494.60 \\
\hline & SSRR & 448.6 & 30666.4 & 30666.4 & 569.5 & 30666.4 \\
\hline & $N$ iterations & 6 & 2 & 6 & 8 & 6 \\
\hline
\end{tabular}

Residual mean square (RMS); squares sum of the regression residuals (SSRR); number (N). For Brody, Von Bertalanffy, Logistic and Richards, the parameter A (g) is the weight at maturity, $\mathrm{K}\left(\mathrm{d}^{-1}\right)$ is the maturity rate, B is a constant of integration without biological interpretation and C for Richards is also the integration constant. For Gompertz, A (g) is the maturity weight; $B\left(d^{-1}\right)$ is the maturity rate and $C(d)$ is the time to maximal growth.

\section{DISCUSSION}

Choosing the best model to describe the quail growth is extremely important to help the researchers make better decisions. According to Fitzhugh Jr. \& Taylor (1976) in the minimum three items should be analyzed to choose the best model: the possibility of biological interpretation of the parameters, adjustment quality and computational difficulties. On this assumption, the results found in this work are correct, since all these items were considered in the evaluation method used. However, Mota et al. (2015), showed other criteria for choosing the best model to describe the growth curve of genetic groups of quail, such as, adjusted determination coefficient $\left(R^{2}\right)$, the asymptotic standard deviation, the average deviation absolute of the residues, the asymptotic index, the Bayesian information criterion, Akaike criterion and the mean square of the error. 
Several authors use the coefficient of determination $\left(R^{2}\right)$ as evaluator of the adjustment quality. Mota et al. (2015) described the growth curve of genetic groups of quail, used the coefficient of determination $\left(R^{2}\right)$ as evaluator of the quality adjustment quality, as well as Freitas (2005) and Guimarães et al. (2006). However, Paz et al. (2004) states that, for non-linear models, $R^{2}$ is not easily defined. Schabenberger (2001) corroborates this assertion by stating that, in the case of non-linear models, a measure relatively near to the $R^{2}$ is obtained by square sums of the residue and the square sums of the total corrected for the mean. Moreover, Drumond et al. (2013), states that $R^{2}$ would not be a good indicator for presenting high values, when it was used to evaluate the adjustment quality of different nonlinear models to the data body growth of meat-type quail from 1 to 42 days of age. Thus, we can say that the evaluation quality adjustment conducted in this work, based in RMS and SSRR was more appropriate than in the other aforementioned studies.

A large number of iterations may indicate inappropriate models, that is, the smaller the number of iterations, to indicate the better adjustment of the nonlinear model to the data (Dhanoa et al., 1995). However, the number of parameters in the model interferes in the possible combinations, requiring higher computational capacity of according with the increases of number of parameters, resulting in a greater number of iterations to achieve convergence (Mello et al., 2008).

The Gompertz model was also the best in quality adjustment for meat-type (Drumond et al., 2013; Grieser et al., 2015, and Mota et al., 2015) and Japanese laying-type quail (Narinc, 2010; Grieser et al., 2015; Finco et al., 2016). In this work, Gompertz also showed a good quality adjustment, standing out from the other models for the description of the organs weight and carcass parts of meat-type and laying-type quail strain.

Another model that stood out in the adjustment quality for some variables of organs weights and parts of the carcass in the present work was the logistic model. A similar result was reported by Mota et al. (2015), evaluating meat-type and laying-type quail from one to 35 days of age, who described that the Logistic model also presented a good adjustment quality to the data for the description of the body growth, besides of Von Bertalanffy and Gompertz models.

For some variables studied the Von Bertalanffy model showed to be a good option, as for the liver, thighs and drumsticks, black and breast for the meat- type quail strain and back and breast for the yellow strain. Some authors as Veloso et al. (2015), already indicated the Von Bertalanffy model for the description of body growth of colonial-type broilers, using an experimental period of one to 84 days of age.

For the description of gut growth in terms of length increase, the model that best adjustment the data for the three quail strain studied was Brody. In contrast to the present study, several are the authors in the literature (Mota et al., 2015; Veloso et al., 2015; Finco et al., 2016), that It wasn't recommended the use of Brody for the description of bird growth, due to low quality adjustment to the data. However, as the present work deals of data of gut length and not of weight of the variable in question, and by the increase of gut length be rapidly in the first days after the birth of the quail, It are some peculiarities that may explain this better adjustment of Brody, already that this model is not indicated to predict the live weight in the early stages of animal growth (Brody, 1945).

The literature of animal production shows that, in general, there are differences in observations when the data are analyzed separately by gender. A work comparing non-linear models to describe the male quails growth and females quails of birth to 42 days of age observed that there was a better adjustment of the Logistic model for females and Gompertz for males (Drumond et al., 2013), respectively. However, Rossi et al. (2014), demonstrated that despite the evolution of body weight of quail present similar behavior, the values are different, concluding that it is important to adjust models for the growth curve separately.

The criteria for the selection of the models were sufficient to decide the best model. The Gompertz model was the most appropriate to describe the organs growth and body components in meat-type and laying-type quail when evaluated in growth phase.

\section{REFERENCES}

Brody S. Bioenergetics and growth. New York: Hafner Press; 1945. 1023p.

Carneiro APS, Muniz JA, Carneiro PLS, Malhado CHM, Martins Filho R, Silva FF. Identidade de modelos não lineares para comparar curvas de crescimento de bovinos da raça Tabapuã. Pesquisa Agropecuária Brasileira 2014;49(1):57-62

Dhanoa, MS, France, J, Siddons, RC, Lopez, S, Buchanan-Smith, JG. A nonlinear compartmental model to describe forage degradation kinetics during incubation in polyester bags in the rumen. British Journal of Nutrition 1995;73:3-15

Drumond ESC, Gonçalves FM, Veloso RC, Amaral JM, Balotin LV, Pires AV, et al. Curvas de crescimento para codornas de corte. Ciência Rural 2013;43:1872-1877. 
Grieser DO, Furlan AC, Ribeiro PM, Zancanela V, Del Vesco AP, Gasparino E Zardin AMSO, Marcato SM

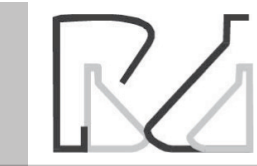

Fialho FB. Interpretação da curva de crescimento de Gompertz [comunicado técnico 237]. Brasília: Embrapa-Cnpsa;1999. p.1- 4

Finco EM, Marcato SM, Furlan AC, Rossi RM, Grieser DO, Zancanela V, et al. Adjustment of four growth models through Bayesian inference on weight and body nutrient depositions in laying quail. Revista Brasileira de Zootecnia 2016:45:737-744.

Fitzhugh Jr HA, Taylor SCS. Analysis of growth curves and strategies for altering their shape. Journal of Animal Science 1976;2:1036-1051.

Freitas AR, Albino LF, Rosso LA. Estimativas do peso de frangos machos e fêmeas através de modelos matemáticos [comunicado técnico, 68]. Brasília: Embrapa-Cnpsa; 1983. p.1- 4.

Freitas AR. Curvas de crescimento na produção animal. Revista Brasileira de Zootecnia 2005:34:786-795.

Gous RM, Moran Jr ET, Stilborn HR, Bradford GD, Emmans GC. Evaluation of the parameters needed to describe the overall growth, the chemical growth, and the growth of feathers and breast muscles of broilers. Poultry Science 1999;78:812-821.

Grieser DO, Marcato SM, Furlan AC, Zancanela Z, Ton APS, Batista E, et al. Comparison of growth curve parameters of organs and body components in meat- (Coturnix coturnix coturnix) and laying-type (Coturnix coturnix japonica) quail show interactions between gender and genotype. Bristish Poultry Science 2015;56:6-14.

Guimarães VP, Rodrigues MT, Sarmento JLR, Rocha DT. Utilização de funções matemáticas no estudo da curva de lactação em caprinos. Revista Brasileira de Zootecnia 2006;35:535-543.

Hancock CE, Bradford GD, Emmans GC, Gous RM. The evaluation of growth parameters of six strains of commercial broiler chickens. British Poultry Science 1995;36:247-64

Marcato SM, Sakomura NK, Fernandes JBK, Siqueira JC, Dourado LRB, Freitas ER. Crescimento e deposição de nutrientes nos órgãos de frangos de corte de duas linhagens comerciais. Revista Brasileira de Zootecnia 2010;39:1082-1091.

Mello, R, Magalhães, ALR, Breda, FC, Regazzi, AJ. Modelo para ajuste de produção de gases em silagem de girassol e milho. Pesquisa Agropecuária Brasileira 2008;43:261-269.

Mota LFM, Alcântara DC, Abreu LRA, Costa LS, Pires AV, Bonafé CM, et al. Crescimento de codornas de diferentes grupos genéticos por meio de modelos não lineares. Arquivos Brasileiros de Medicina Veterinária e Zootecnia 2015:67:1372-1380.

\section{Comparison of the Quality Adjusting of Nonlinear Models for Organs, Carcass and Body Components in Meat-Type (Coturnix Coturnix Coturnix) and Laying- Type (Coturnix Coturnix Japonica) Quail}

Narinc D, Karaman E, Firat MZ, Aksoy T. Comparison of non-linear growth models to describe the growth in Japanese quail. Journal of Animal and Veterinary Advances 2010;9:1961-1966.

Nelder JA. The fitting of a generalization of the logistic curve. Biometrics $1961 ; 17: 89-110$

Neme R, Sakomura NK, Fukayama EH, Freitas ER, Fialho FB, Resende KT, et al. Curvas de crescimento e deposição dos componentes corporais de aves de postura de diferentes linhagens. Revista Brasileira de Zootecnia 2006;35:1091-1100.

Pasternak $\mathrm{H}$, Shalev BA. The effect of a feature of regression disturbance on the efficiency of fitting growth curves. Growth, Development and Aging 1994;58:33-39.

Paz CCP, Packer IU, Freitas AR, Tambasco DD, Regitano LCA, Alencar MM. Ajuste de modelos não lineares em estudos de associação entre polimorfismos genéticos e crescimento em bovinos de corte. Revista Brasileira de Zootecnia 2004;33:1416-1425.

Richards FJ. A flexible growth function for empirical use. Journal of Experimental Botanic 1959;10:290-300.

Rossi RM, Dos Santos LA. Modelagem Bayesiana para curvas de crescimentos de codornas assumindo assimetria nos erros. Semina Ciências Agrárias 2014;35:1637-1648.

Rostagno HS, Albino LFT, Donzele JL, Gomes PC, Oliveira RF, Lopes DC, et al. Tabelas brasileiras para aves e suínos: composição de alimentos e exigências nutricionais. $2^{\text {nd }}$ ed. Viçosa: UFV; 2011. p.252.

Sakomura NK, Longo FA, Oviedo-Rondon EO, Boa-Viagem C, Ferraudo A. Modeling energy utilization and growth parameter description for broiler chickens. Poultry Science 2005;84:1363-1369.

Sakomura, NK, Rostagno, HS. Métodos de pesquisa em nutrição de monogástricos. $2^{\text {nd }}$ ed. Jaboticabal: Funep; 2016. p.262.

Schabenberger $\mathrm{O}$. Non linear regression with the SAS system. Cary: SAS Institute; 2001.

SAS. Statistical Analyses System. Version Release 8.2. for Windows [CDROM]. Cary; 2001.

Veloso RC, Pires AV, Torres Filho RA, Drumond ECS, Costa LS, Amaral JM, et al. Crescimento de genótipos de frangos tipo caipira. Arquivo Brasileiro de Medicina Veterinária e Zootecnia 2015;67:1361-1371.

Von Bertalanffy L. Quantitative laws in metabolism and growth. The Quarterly Review of Biology 1957;32:217-230. 